Article

\title{
Representation of Women in the News: Balancing between Career and Family Life
}

\author{
Hanne Vandenberghe \\ Institute for Media Studies, KU Leuven, 3000 Leuven, Belgium; E-Mail: hanne.vandenberghe@kuleuven.be
}

Submitted: 15 June 2018 | Accepted: 28 September 2018 | Published: 5 February 2019

\begin{abstract}
An in-depth literature review showed that women, despite their increasingly prominent roles worldwide, continue to be persistently underrepresented and stereotyped in news media. This study aimed to investigate the extent to which the representation of women changed over time in two Dutch-speaking Belgian newspapers De Standaard and Het Laatste Nieuws. An automated quantitative content analysis revealed that there is no increase of the number of women in the newspapers between 2005 and 2015. On the contrary, women are significantly less represented over time in the popular newspaper Het Laatste Nieuws. A qualitative analysis on two cases about women stepping into a leadership positionin 2012 (Catherine De Bolle as head of the Federal police) and in 2014 (Dominique Leroy as CEO of a Belgian telecom company)-showed that the press emphasised their femininity, their being a role model for other women, their being part of a family and having certain looks. Moreover, these women are clearly portrayed as 'the best candidate' pointing at the selection procedures and their capabilities to perform professionally. Probably, this strong emphasis is a way of justifying that these women are not selected because of positive discrimination. Further analysis of cases of both men and women stepping into top positions across countries and media platforms is recommended.
\end{abstract}

\section{Keywords}

content analysis; Dutch-speaking press; gender; news; representation; stereotyping; women

\section{Issue}

This article is part of the issue "Communicating on/with Minorities", edited by Leen d'Haenens and Willem Joris (KU Leuven, Belgium).

(C) 2019 by the author; licensee Cogitatio (Lisbon, Portugal). This article is licensed under a Creative Commons Attribution 4.0 International License (CC BY).

\section{Introduction}

Since the 1970's the representation of women in the media is high on the political and research agenda (e.g., Ross, Boyle, Carter \& Ging, 2016). An illustrative example is the 1995 'Beijing Declaration and Platform of Action' (UN Women, 1995) in which media are assumed to play an important role in achieving gender equality. This role is formulated in Article 33 as follows: "The media have a great potential to promote the advancement of women and the equality of women and men by portraying women and men in a non-stereotypical, diverse and balanced manner". The role of media is reemphasised in Article 44 of the Declaration, stating that: "Governments...are called upon to take strategic action in the following critical areas of concern: stereotyping of women and inequality in women's access to and partici- pation...in the media". The Declaration thus encourages the development and implementation of regulation on gender equality.

Gender equality is a multifaceted concept. The global gender gap index is composed of the following four aspects: economic participation and opportunity, educational attainment, health and survival, and political empowerment (World Economic Forum, 2017). The gender equality index on European level is based on six domains: i.e., work, money, knowledge, time, power and health (European Institute for Gender Equality [EIGE], 2017). Previous research focused on gender within a political context (e.g., Ross, Evans, Harrison, Shears, \& Wadia, 2013; Vos, 2012). However, this study will focus on the professional context of women, more specifically in Belgium. Between 2006 and 2017 Belgium dropped from place 20 to place 31 on the global gender gap index 
ranking, although the gender equality index increased from .71 to .74 (World Economic Forum, 2017). Specifically for the 'economic participation and opportunity' category, gender equality improved from .62 to .72 (respectively an increase from place 54 to place 46 ).

According to the EIGE, on the European level gender increased from $62 \%$ in 2005 to $66 \%$ in 2015 (EIGE, 2017). Moreover, the proportion of women on the boards of the largest listed companies is more than doubled between 2005 and 2015 (from 10\% to 22\%), with the highest increase in Belgium, France, Italy and the Netherlands. The overall gender equality score in Belgium increased from $66 \%$ to $71 \%$ in that period.

The Beijing Declaration identifies two aspects of fair gender representation: gender equality in numbers, i.e., the quantitative approach, and in the manner of representation, i.e., the qualitative approach. This study has also a twofold aim. Firstly, as the gender equality index increased over time, this study will map the evolution of the number of female news actors between 2005 and 2015 in two Dutch-speaking Belgian newspapers. Secondly, it will look at the way in which women who stepped into a leading position in the same period are stereotyped by analysing two cases in the same two newspapers.

\section{Is gender Equality in Sight?}

\subsection{The Persistent Underrepresentation of Female News Actors}

It seems that gender equality is still an elusive dream despite the increasingly prominent roles-also specifically in top segments - of women worldwide (e.g., Humprecht \& Esser, 2017; Ross et al., 2016). An in-depth literature review shows that women are still underrepresented in news contexts.

Following the Beijing Declaration, the UN Women launched the Global Media Monitoring Project to evaluate the extent of gender equality in news media. Since 1995 , every five years a research team reports the menwomen ratio of news sources worldwide. The most recent results from 2015 identified a gender imbalance pointing at $24 \%$ female versus $76 \%$ male news sources (World Association for Christian Communication [WACC], 2015). Between 1995 and 2015, there was only a slow increase of $7 \%$ in women's visibility in the news. Compared to radio and television news, the number of women increased the most in newspapers, i.e. from $16 \%$ in 1995 to $26 \%$ in 2015. The European results hardly differ from the overall pattern: in $\mathbf{2 0 1 5}$ there were $25 \%$ women in traditional news media, which was an increase of $9 \%$ over the last 20 years.

In a US context, both in newspapers (e.g., Armstrong, 2004; Zoch \& VanSlyke Turk, 1998) and in television news (e.g., Liebler \& Smith, 1997) female actors are underrepresented compared to their male counterparts. In general, 70 to $80 \%$ men against 30 to $20 \%$ women were reported on. Moreover, men were proportionally more cited in front pages and longer articles (Zoch \&
VanSlyke Turk, 1998), as well as in titles and introductions (Armstrong, 2004).

A similar trend is found in longitudinal analysis of Russian, Estonian and Finnish newspapers between 1905 and 2005 (Kõuts \& Lõhmus, 2014). The percentage of female actors remained under $10 \%$ in Russian newspapers. Finnish newspapers represented on average $5 \%$ women, only in the 1990's female actors reached a peak of more than $10 \%$. The Estonian data revealed an explicit increase of women over time: from under $10 \%$ until the 1970 s to 20 to $25 \%$ since the 2000 s. However, on average the number of women was limited in the three countries.

The analysis of election reporting in British newspapers in 2010 tells a similar story. In $71 \%$ of the articles no female actor was mentioned, whereas this was only the case in $8 \%$ of the articles for male actors. The total menwomen ratio for speaking actors was 84 against 16 (Ross et al., 2013).

A more recent study of English online news sites found that men are dominating the news stories both in texts and images (Jia, Lansdall-Welfare, Sudhahar, Carter, \& Cristianini, 2016). In texts, male dominance ranged from $70 \%$ in entertainment stories to $92 \%$ in sports articles. For images, the overrepresentation of men was the smallest in entertainment (59\%) and the largest in political news (80\%). Fashion news was the only exception were women proportionally were overrepresented both in texts (54\%) and images (64\%). Similar conclusions were formulated by Matud, Rodríguez and Espinosa (2011) based on an analysis of the Spanish quality newspaper El Mundo where women also only dominated the news stories as models or winners of beauty contests.

A study of the Dutch-speaking Belgian television news coverage (De Swert \& Hooghe, 2010) indicated that in 2003, 2004 and 2005 respectively in 34\%, 36\% and $42 \%$ of the news stories a woman was given a voice. Despite the increasing trend, in only two out of five news items a female source was found. Another Flemish television news study (Hooghe, Jacobs, \& Claes, 2015) focused on the news coverage of female MPs. Women were underrepresented in comparison with the real number of women in parliament. Moreover, females were given less speaking time compared to their male colleagues. Not only in Flemish television news stories were women underrepresented, a recent study both in traditional print media and online news sites revealed a gender imbalance of $20 \%$ female actors in comparison with $80 \%$ male actors (De Vuyst, Vertoont, \& Van Bauwel, 2016).

To conclude, women are persistently underrepresented in news contexts worldwide with a ratio of approximately 3 male actors for every female one, referring to the so-called $\mathrm{R}^{3}$ hypothesis (Rush, Oukrop, \& Sarikakis, 2005). However, between 2005 and 2015 the gender equality index in Belgium increased from $66 \%$ to $71 \%$. This study will analyse whether the underrepresentation of women changed over time in the Dutch-speaking Belgian press. Consequently, the first research question (RQ1) reads as follows: to which extent did the number 
of female news actors increase over time (2005-2015) in Dutch-speaking Belgian newspapers?

\subsection{Are Female Leaders Framed as Professionals?}

Although a quantitative approach on gender equality is valuable, it is also important to take into account how females are represented. Research revealed that typical female roles in news stories are women as spouses or mothers, and only occasionally as politicians or professionals (Ross et al., 2016). The Global Media Monitoring Project, for instance, found that worldwide women are five times more mentioned in news stories because of their family status than men (WACC, 2015). A study by Ross and Carter (2011) in British newspapers showed that women are three times more likely than men to be associated with their family situation. A Flemish study indicated that women are significantly more often represented in a family context than men (De Vuyst et al., 2016).

The main focus of this study is to analyse how women in a leading position are being framed in a news context. Earlier studies focusing on the representation of female politicians revealed that women are often associated with their family contexts, looks and age (Vos, 2012) and the fact that they were women was emphasised, resulting in less attention to their actual positions (Ross et al., 2013). This resulted in RQ2: how are women who stepped into a leadership position being framed as professionals in Dutch-speaking Belgian newspapers?

In sum, women are not only less represented in news stories, there are also presented in a different way. As the Beijing Declaration stated, it is important to strive for a diverse manner of representation to achieve gender equality. Systematic under- or misrepresentation of women is both contradictory with social reality and resulting in reducing the social status of women (e.g., Tuchman, 1978). A study confirmed that a higher share of female actors in all kind of news stories had a significant positive effect as well on gender equality in the country as on attitudes on gender roles among the country's population (DjerfPierre, 2011). The purpose of this study is to investigate to which extent women play an important role in Dutchspeaking newspapers.

\section{Method}

A multi-method approach was used to investigate the two research questions. To map the evolution of female actors between 2005 and 2015, a quantitative automatic content analysis tool was created by the software developer Zeticon. News articles of two Dutchspeaking Belgian newspapers were collected from the Belgian press database GoPress. The selected newspapers are the most widely read quality paper De Standaard and the most read tabloid Het Laatste Nieuws. In total 3.961.654 news articles were detected of which $14.7 \%$ was published in the quality paper and $85.3 \%$ in the tabloid paper. This imbalance can be explained by the large amount of regional editions (approximately between 20 and 25 regional editions in the period under investigation) of Het Laatste Nieuws in contrast with only 5 regional editions of De Standaard. Within the news stories, the gender of the actors was derived from the Knowledge Base Freebase, which was mainly based on information available at Wikipedia. Consequently, gender was not assigned to unknown or ordinary people such as a witness of an accident. In total, the tool identified $16,634,712$ actors (16.7\% of De Standaard and $83.3 \%$ of Het Laatste Nieuws). Gender was assigned to $3,118,881$ actors or $18.7 \%$ of the total sample. The division between De Standaard and Het Laatste Nieuws was $34 \%$ versus $67 \%$. Consequently, proportionally gender was more assigned to actors in De Standaard (38.3\%) than in Het Laatste Nieuws (14.8\%). Again, the regional focus in Het Laatste Nieuws applies as an explanation. Regional articles tend to cover more unknown people who are not included in the Knowledge Base. The performance indicators for assigning gender on the basis of the Knowledge Base (precision value of 0.98 , recall value of 0.88 and F-measure of 0.93 ) can be considered as good to excellent (Habryn, 2014).

To answer the second research question, two cases were found in which a woman stepped into a leadership position in Belgium between 2005 and 2015. Women who became CEO were searched for via the phrase "female CEO" (vrouwelijke CEO in Dutch) in Google. This search resulted in the following names: Michèle Sioen who became head of Sioen Industries in 2005, Ingrid Ceusters who became CEO of Hugo Ceusters Group in 2007, Sandra De Preter who became CEO of the public service broadcaster in 2010, Catherine De Bolle who became Commissioner-general of the Belgian Federal Police in 2012, Dominique Leroy who became CEO of Proximus in 2014 and Saskia Van Uffelen who became CEO of Ericsson Benelux in 2014. Other names such as Ingrid Lieten and Françoise Chombar became CEO before 2005, respectively in 2001 as head of the public bus transport company De Lijn and as CEO of Melixis in 2004. Via the Belgian press database GoPress articles were collected in the same two newspapers De Standaard and Het Laatste Nieuws. Articles were selected based on the name of the woman and the moment they were appointed as CEO. Only the cases of Catherine De Bolle and Dominque Leroy were selected, because at least 4 articles were found in both newspapers. For instance, about Ingrid Ceusters no articles were found. The sample about Catherine De Bolle comprised 38 articles published between 2 August 2011 and 31 March 2012 of which 17 articles appeared in De Standaard and another 21 in Het Laatste Nieuws. The second case refers to Dominque Leroy who became CEO of the Belgian telecom company Proximus (formerly known as Belgacom) in 2014. Proximus is an autonomous public-sector company, which explains why the CEO position needs to be approved by the Belgian Government. The sample on the case of Dominique Leroy is composed of 39 articles of 
which 24 were published in De Standaard and 15 in Het Laatste Nieuws. The selected articles were published between 9 November 2013 and 25 February 2014. To analyse the extent to which these two women were framed in the newspapers, a qualitative text analysis was conducted on all 77 news stories. Each article was divided into three categories based on the article length: a short article counting less than 150 words, a medium article counting between 150 and 300 words, and a large article counting more than $\mathbf{3 0 0}$ words. Secondly, three categories are used to indicate how Catherine De Bolle and Dominique Leroy were mentioned in the article: (1) as the subject of the article, Catherine De Bolle/Dominique Leroy was only mentioned, (2) as the subject of the article, Catherine De Bolle/Dominique Leroy was cited or paraphrased, (3) Catherine De Bolle/Dominique Leroy was only mentioned in the margin of the article.

Articles of the two cases were coded based on a theoretical thematic analysis (Braun \& Clarke, 2006). The analysis consisted of the following stages. First, the articles were read in detail and open codes were attributed. In the next stage, selective coding was used to merge the identified codes into nine main themes: being a woman, being an exemplary role model, referring to the family situation, proposed as the best candidate, listing the capabilities, dealing with the male environment (so-called male bastion), referring to positive discrimination, referring to looks and mentioning the age. The main themes 'being a woman', referring to looks' and 'mentioning the age' were in line with previous studies on the representation of female politicians (Ross et al., 2013; Vos, 2012). In the results section, the findings will be discussed and illustrated with quotations from the articles.

\section{Results}

\subsection{Are Women Climbing Up or Slipping Down the Social Ladder?}

Table 1 gives an overview of the percentage of female actors between 2005 and 2015 in both newspapers un- der study. A linear regression analysis showed no significant increase of the number of female actors over time in De Standaard $(r=-.28, p>.05)$. The average gender ratio was $12.8 \%$ female actors against $87.2 \%$ male actors $(S D=.66)$. The lowest percentage was found in 2011 (11.8\%) and the highest in 2015 (13.9\%). However, instead of an increase of female actors over time in Het Laatste Nieuws, a linear regression analysis showed a significant decrease $(r=-.65, p=.03)$. The highest percentage of women was found in 2005 (10.9\%) and the lowest in $2010(8.1 \%)$. The average man-woman ratio was 90.5:9.5 (SD = .95). Moreover, on average significantly more female actors were detected in De Standaard compared to Het Laatste Nieuws, $t(10)=14.49, p<.001$.

\subsection{Journalists Emphasise the Femininity of Female Leaders}

In the next section, the particular cases of the candidacy and appointment of both Catherine De Bolle as head of the Federal Police and Dominque Leroy as CEO of the telecom company Proximus will be discussed.

\subsubsection{The Case of Catherine De Bolle as Head of the Federal Police}

Half of the articles about Catherine De Bolle counted less than 150 words of which five were even shorter than 100 words. Two out of five articles were longer than 300 words. As Table 2 shows, the categorisation on how Catherine De Bolle was mentioned in the articles was the following: 17 as the main subject, 5 articles in which she is cited and 16 articles in which she is only mentioned in the margin of the article. The occurrence of the nine thematic categories is also listed in Table 2 . In the next part, each category will be discussed.

In 28 of the 38 articles the fact that Catherine De Bolle is a woman is explicitly stated. In 22 of these 28 articles being a woman is presented in a neutral tone. In 20 articles this was expressed as 'being the first woman for the leadership position of the Federal police'. Although

Table 1. The percentage of female actors with respect to the total number of actors by whom gender was assigned between 2005 and 2015 both in the quality paper De Standaard and the popular paper Het Laatste Nieuws.

\begin{tabular}{lll}
\hline & De Standaard $(\boldsymbol{n}=\mathbf{1 . 0 6 1 . 6 5 4})$ & Het Laatste Nieuws $(\boldsymbol{n}=\mathbf{2 . 0 5 7 . 2 2 7})$ \\
\hline 2005 & 13.2 & 10.9 \\
2006 & 13.2 & 10.4 \\
2007 & 13.4 & 10.8 \\
2008 & 13.1 & 10.0 \\
2009 & 12.7 & 8.6 \\
2010 & 12.5 & 8.1 \\
2011 & 11.8 & 8.6 \\
2012 & 12.0 & 9.3 \\
2013 & 12.3 & 9.1 \\
2014 & 12.3 & 8.8 \\
2015 & 13.9 & 9.4 \\
\hline
\end{tabular}


Table 2. Total number of articles mentioning the specific labels in the selected news articles about Catherine De Bolle and Dominique Leroy.

\begin{tabular}{|c|c|c|}
\hline & Catherine De Bolle & Dominque Leroy \\
\hline Being a woman (1) & 28 & 17 \\
\hline De Standaard & 15 & 10 \\
\hline Het Laatste Nieuws & 13 & 7 \\
\hline Being an exemplary role model (2) & 2 & 3 \\
\hline De Standaard & 0 & 1 \\
\hline Het Laatste Nieuws & 2 & 2 \\
\hline Family situation (3) & 6 & 4 \\
\hline De Standaard & 1 & 2 \\
\hline Het Laatste Nieuws & 5 & 2 \\
\hline Best candidate (4) & 15 & 7 \\
\hline De Standaard & 7 & 5 \\
\hline Het Laatste Nieuws & 8 & 2 \\
\hline Capabilities (5) & 10 & 12 \\
\hline De Standaard & 4 & 9 \\
\hline Het Laatste Nieuws & 6 & 3 \\
\hline Male bastion (6) & 5 & 1 \\
\hline De Standaard & 3 & - \\
\hline Het Laatste Nieuws & 2 & 1 \\
\hline Positive discrimination (7) & 5 & 4 \\
\hline De Standaard & 2 & 2 \\
\hline Het Laatste Nieuws & 3 & 2 \\
\hline Looks (8) & 6 & 4 \\
\hline De Standaard & 1 & 3 \\
\hline Het Laatste Nieuws & 5 & 1 \\
\hline Age (9) & 9 & 6 \\
\hline De Standaard & 3 & 1 \\
\hline Het Laatste Nieuws & 6 & 5 \\
\hline Main subject (only mentioned) & 17 & 12 \\
\hline De Standaard & 10 & 8 \\
\hline Het Laatste Nieuws & 7 & 4 \\
\hline Main subject (cited) & 5 & 7 \\
\hline De Standaard & 2 & 3 \\
\hline Het Laatste Nieuws & 3 & 4 \\
\hline Not main subject & 16 & 20 \\
\hline De Standaard & 5 & 13 \\
\hline Het Laatste Nieuws & 11 & 7 \\
\hline Total & 38 & 39 \\
\hline
\end{tabular}

a more negative tone was found in an opinion article in De Standaard (January 13th) wherein a female expert criticised the blatant focus on the fact that Catherine De Bolle is a woman in a top position. In another article in De Standaard (October 7th) Catherine De Bolle is called by an ex-colleague: "our madam", which has a rather pejorative connotation in Dutch. Besides, Catherine De Bolle stated: "I will not focus on female accents" (article publish March 1st in Het Laatste Nieuws), which is a clear statement that she will not use her femininity in her job. In the same article, however, she described being a woman in a positive way as follows: "I am proud that being a woman I have scored the best in the selection tests". Another example of a positive connotation is an ex-colleague who describes her as "the mother of the house" (Het Laatste Nieuws, March 2nd).

In two articles the leading position of Catherine De Bolle is given as an example for other women. Catherine De Bolle stated as follows: "I am happy for all women. I have proven that there are career opportunities and that we [women] can achieve top positions" (Het Laatste Nieuws, March 1st). The mayor of her hometown also indicated that "she is an example for all women" (Het Laatste Nieuws, March 31st).

Her family situation is mentioned explicitly in six articles. In five articles her being a mother is mentioned in a neutral way. This is once indicated by her former boss, who also stated that Catherine De Bolle is very discrete 
about her private life (Het Laatste Nieuws, January 12th). Only in one article (Het Laatste Nieuws, March 1st) she indicated herself that combining her job with a family is challenging, however she emphasises this is not only the case for women but also for men. She also stated that her children's reactions about her job were positive: "They are proud of me. That feels good".

In 15 of the 38 articles it is explicitly stated that Catherine De Bolle is the best candidate for the position according to the tests. It is clear that she is selected because she had the best results on all the tests. Or as the mayor of her hometown stated in the article of March 31st in Het Laatste Nieuws: "Catherine had climbed to the top on her own and had the best results on the tests". As already mentioned, Catherine De Bolle stated that she is proud to be both a woman and have the best results on the selection tests (Het Laatste Nieuws, March 1st). In another article she also said: "I simply was the first according to the selection criteria" (De Standaard, March 1st).

The capabilities of Catherine De Bolle are mentioned in ten of the 38 articles. In one case only, the journalist doubted about her abilities because of the lack of experience at the non-local level (De Standaard, January 11th). In the other nine cases, her qualities are highlighted, ranging from being smart, being determined, having a clear vision to being able to collaborate. Both ex-colleagues, journalists, friends and a criminologist described her talent. For instance, an ex-colleague described her as follows: "A good boss. She listens to everyone and has no macho behaviour at all" (Het Laatste Nieuws, October 7th). In one article Catherine De Bolle stated herself: "I am willing to listen, I prefer to make decisions in all openness.... am not an iron lady who ignores the opinions of others" (Het Laatste Nieuws, March 1st). Overall, her capabilities are described in sharp contrast with the former head of the police, who was fired.

Five articles referred to the police context as a men's world. This 'men's world' is twice described as a 'male bastion' by journalists in Het Laatste Nieuws and once in an opinion article by a female expert in De Standaard. Catherine De Bolle refers twice to this male environment. In the first example she tells the following story: "In $1994 . . . m y$ superiors were not used to women....It was very confronting to enter this men's world....Nowadays, it is much easier as a woman to stand your ground" (De Standaard, October 7th). A second time she said: "I am used to work in a men's world" (De Standaard, March 1st).

Positive discrimination is mentioned five times. Twice explicitly in the sense that Catherine De Bolle is against preferential treatment. An example: "Although Catherine is a real woman, she never used it to be favoured....She is against all kinds of discriminatory actions. A woman needs to prove her professionalism just like a man", stated by an ex-colleague in the article of January 12th in Het Laatste Nieuws. Catherine De Bolle referred also implicitly to positive discrimination, claim- ing the following: "People with common sense choose the best candidate, regardless of gender" (De Standaard, October 7th) and "Like the male candidates, I simply participated in the selection process, on which I scored the best. It proves that a woman can also reach the top within the police force" (De Standaard, March 1st).

In six articles we came across references to Catherine De Bolle's physical appearance, most of the time referring to her short stature. One time a journalist of Het Laatste Nieuws (March 1st) characterised her appearance "punchy". She also indicates in the same article the lack of femininity of the police uniforms, especially the fact that the insignia and name cards are worn at chest height.

Finally her age is explicitly mentioned in nine of the 38 articles, mostly between brackets. No extra information is given about her age. In one article of Het Laatste Nieuws the ages of her three children are also given.

\subsubsection{The Case of Dominque Leroy as CEO of the Telecom Company Proximus}

The majority of the articles-26 out of 39-about Dominque Leroy counted at least 300 words. Only five articles were categorised as 'short' and eight as 'medium' in length. As Table 2 indicates, in almost half of the articles Dominique Leroy was not the main subject. Overall, more attention is paid to Dominique Leroy in De Standaard compared to Het Laatste Nieuws (24 articles against 15 articles). Taking the same analytical approach to the coverage of Catherine De Bolle, the following analysis of Dominque Leroy will be structured around nine thematic concerns (see Table 2).

The fact that Dominique Leroy is a woman is explicitly emphasised in 17 articles. In 10 of these 17 articles, the fact that Dominque Leroy is a woman is formulated in an explicitly neutral way. Six times she is described as being the first woman occupying this high position. In several articles her gender is described positively. Journalists were positive in the following two examples: "A woman. Interesting for a government that wants to excel in opportunities for women" (Het Laatste Nieuws, November 18th) and "The appointment of Dominque Leroy is an encouragement because she will be the first woman in charge of a Bel20-company" (De Standaard, January 9th). A more negative connotation about women in general is found in an opinion article in De Standaard (January 11th), although Dominique Leroy seems to be an exception: "She does not even seem to be a bitch". However, a gender-neutral approach is also used, e.g. in an article published November 15th in De Standaard where the successor of the current CEO is named as follows: "successor (m/f)".

In three articles Dominique Leroy is presented as a role model for other women. A professor stated that her position as CEO of a listed company is an important role model (Het Laatste Nieuws, January 9th). In a second article in De Standaard (January 10th) Dominique Leroy ex- 
presses her leadership position as a good example of the necessary gender balance in companies. She describes herself also as a role model in Het Laatste Nieuws (January 11th) when she answers the question "how proud are you to be the first female CEO of Belgacom?" with "It makes me definitely happy. I have always encouraged women to develop".

In seven articles Dominique Leroy is presented as the best candidate for the CEO position. She ended highest according to headhunter Russell Reynolds. The then Minister of public companies Labille stated in Het Laatste Nieuws (January 10th) the following: "Her profile fits best with this function". Also a list of her capabilities makes it clear she is the right person. In 12 articles her capabilities are presented in a positive way, both by the journalist, the Minister and (ex-)colleagues. Some examples are references to her experience, her reputation, her multilingualism (especially speaking both important national languages) and her strong clear-eyed vision. A good illustration of the way Leroy's professionalism and experience is expressed is reflected in the following quote, expressed by a CEO of a company of which Dominque Leroy is a board member: "She is always well prepared and organised, has a sound body of knowledge and comes up with fresh ideas" (De Standaard, January 9th). However, in one of the articles a slightly negative tone is found where insiders stated that her promotion is a little bit early (De Standaard, January 9th), although in the same article she is called "the right person to work in the consumer market".

Only in one article (Het Laatste Nieuws, January 9th) a professor stated that Dominique Leroy's position is an example of a woman in a typical male bastion. She indicates in an interview (Het Laatste Nieuws, January 9th) that being an exception as a woman is something of her past career: "I was the first woman who ate in the management restaurant....Men didn't know how to behave.....Men are now used to the presence of women in high positions, but back in the past, it was uncomfortable".

In four articles the case of Dominique Leroy is linked with positive discrimination; twice it is seen as an example of breaking the glass ceiling. Dominique Leroy supports positive discrimination, and especially the use of quota: "Otherwise, women will be permanently treated as sexual objects instead of competent persons" (stated in a French-speaking magazine and cited in an article published January 9th in De Standaard).

In one article the journalist called it hypocrite not the mention her looks (De Standaard, January 11th). Other striking examples are a description of the dress she is wearing (Het Laatste Nieuws, January 10th), in which she is also called "the Belgacom-queen". In another article (De Standaard, January 10th) a journalist compares her also with the queen: "it seemed as if she was the Queen Mathilde of the towers of Belgacom". Finally, in six articles Dominque Leroy's age is mentioned, mostly between brackets and always with a neutral tone and without any further comment.

\section{Conclusions}

Longitudinal, automated content analysis pointed at a persistent female underrepresentation in the Dutchlanguage press (RQ1). While the best achievement as to gender balance between 2005 and 2015 resulted in 14\% women against $86 \%$ men in 2015 in De Standaard, the worst counted 8\% women against 92\% men in 2010 in Het Laatste Nieuws. Similar to the Russian and Finnish newspapers (Kõuts \& Lõhmus, 2014), there is no increase of the number of female actors over time. This result is in sharp contrast with both the increase of Belgian gender equality scores in reality, as documented by the World Economic Forum and the EIGE, and the more prominent role women play in society. The two selected qualitative cases are vivid illustrations of the latter. Surprisingly, the linear regression analysis showed that the amount of female actors significantly decreased between 2005 and 2015 in the popular newspaper Het Laatste Nieuws. Consequently, significantly more women were mentioned in the quality paper compared to the popular one. Further analysis is needed to clarify this difference. The results are based on an automated coding analysis that only took the gender of actors known in Freebase into account. This is a first limitation of this study. However, this shortcoming cannot explain the gender gap between both newspapers: there is no reason why the number of female actors should be measured less well in Het Laatste Nieuws compared to De Standaard. Another limitation is whether the automatic analysis tool is sufficiently valid. Although the performance indicators are good to excellent, the percentage of female actors is lower than in a subsample based on manual coding. The precision value drops from .98 to .82 when there is no link found in the Knowledge Base, resulting in a lower validity when a person is not listed in the Knowledge Base.

However, the main aim of this study was to analyse whether, and if so, how women are framed as professionals (RQ2). Overall, both Catherine De Bolle and Dominique Leroy are presented very positively as 'the best candidate' who obtained the best results on the selection test. Much attention is paid to the women's qualities to step into the top position. Probably, this emphasis is a manner of justifying that these women are not selected because of positive discrimination. For instance, Catherine De Bolle emphasised clearly she performed best in the selection tests, thus proving that women can hold top positions. Similar cases with a man who stepped into a leadership position should be investigated in further research. A suggestion for such a case is the appointment of Marc De Mesmaeker as head of the Federal police as of last May 2018. Catherine De Bolle is now promoted to a top position at Europol. Her new promotion should also be an interesting case to evaluate the representation of professional women over time.

However, in both cases the fact these women's femininity is emphasised most in the articles. Generally, 'being a woman' is framed in a neutral way, stating that they 
were the first women in such a top position. Although most articles adopted a neutral or positive tone, some more negative connotations were also found. Catherine De Bolle is almost twice as much explicitly described as a woman compared to Dominique Leroy, respectively in 28 out of 38 articles and in 17 out of 39 articles. This discrepancy can be explained by two reasons. Firstly, there are proportionally less articles dealing with Dominique Leroy as a main subject, resulting in only mentioning her in the margin. Secondly, Dominique Leroy held already a top position in the telecom company, whereas Catherine De Bolle was an unknown figure working at local police level. Hence, the appointment of Catherine De Bolle was more unique and therefore newsworthy.

As indicated in previous studies (e.g., De Vuyst et al., 2016; Vos, 2012), in both cases under study, women were linked with their family status, their looks and age. For the sake of comparison, other cases where men stepped into a leadership position should be compared in future research.

Another striking result was that both women reported on a story in their career when they felt uncomfortable as a woman. However, they stated that nowadays it is accepted that a woman takes a position within what has traditionally been perceived as a male domain such as police work. These women indicated that the way they are treated and perceived has changed compared to the 1990s. This study did not find an increase of female actors since 2005. Consequently, to find out whether female representation actually changed over time, future research should go back earlier in time, for instance to the 1990s.

The sample of the qualitative text analysis was small. Future studies with larger sample sizes and/or more cases are recommended. The issue of gender representation and stereotyping is important to monitor continuously to keep a close eye on the matter. Balanced gender representation in news media is an important step to gender equality, as stated in the UN Women Beijing Declaration and proved in research (Djerf-Pierre, 2011).

\section{Acknowledgments}

I would like to thank the editors for giving me the opportunity to publish in this thematic issue. This publication was made possible through funding support of the $\mathrm{KU}$ Leuven Fund for Fair Open Access.

\section{Conflict of Interests}

The author declares no conflict of interests.

\section{References}

Armstrong C. L. (2004). The influence of reporter gender on source selection in newspaper stories. Journalism \& Mass Communication Quarterly, 81(1), 139-154. Braun, V., \& Clarke, V. (2006). Using thematic analysis in psychology. Qualitative Research in Psychology, 3(2), 77-101.

De Swert, K., \& Hooghe, M. (2010). When do women get a voice? Explaining the presence of female news sources in Belgian news broadcasts (2003-2005). European Journal of Communication, 25(1), 69-84.

De Vuyst, S., Vertoont, S., \& Van Bauwel, S. (2016). Sekseongelijkheid in Vlaams nieuws: een kwantitatieve inhoudsanalyse naar de aanwezigheid van vrouwen en mannen in Vlaamse nieuwsverhalen [Gender inequality in Flemish news: A quantitative content analysis of the presence and portrayal of women and men in Flemish news stories]. Tijdschrift voor Communicatiewetenschap, 44(3), 253-271.

Djerf-Pierre, M. (2011). The difference engine: Gender equality, journalism and the good society. Feminist Media Studies, 11(1), 43-51.

European Institute for Gender Equality. (2017). Gender equality index 2017. Measuring gender equality in the European Union 2005-2015. Vilnius: European Institute for Gender Equality.

Habryn, F. (2014). Customer intimacy analytics: Leveraging operational data to assess customer knowledge and relationships and to measure their business impact. Karlsruhe: KIT Scientific Publishing.

Hooghe, M., Jacobs, L., \& Claes, E. (2015). Enduring gender bias in reporting on political elite positions: Media coverage of female MPs in Belgian news broadcasts (2003-2011). The International Journal of Press/Politics, 20(4), 395-414.

Humprecht, E., \& Esser, F. (2017). A glass ceiling in the online age? Explaining the underrepresentation of women in online political news. European Journal of Communication. doi:10.1177/0267323117720343.

Jia, S., Lansdall-Welfare, T., Sudhahar, S., Carter, C., \& Cristianini, N. (2016). Women are seen more than heard in online newspapers. PloS one, 11(2), 1-11.

Kõuts, R., \& Lõhmus, M. (2014). Representation of social actors in Finnish, Estonian, and Russian dailies, 1905-2005. International Communication Gazette, 76(8), 661-681.

Liebler, C.M., \& Smith, S.J. (1997). Tracking gender differences: A comparative analysis of network correspondents and their sources. Journal of Broadcasting \& Electronic Media, 41(1), 58-68.

Matud, M. P., Rodríguez, C., \& Espinosa, I. (2011). Gender in Spanish daily newspapers. Sex Roles, 64(3/4), 253-264.

Ross, K., \&, Carter, C. (2011). Women and news: A long and winding road. Media, Culture \& Society, 33(8), 1148-1165.

Ross, K., Boyle, K., Carter, C., \& Ging, D. (2016). Women, men and news: It's life, Jim, but not as we know it. Journalism Studies. doi:10.1080/1461670X.2016. 1222884

Ross, K., Evans, E., Harrison, L., Shears, M., \& Wadia, K. (2013). The gender of news and news of gender: A study of sex, politics, and press coverage of the 2010 
British general election. The International Journal of Press/Politics, 18(1), 3-20.

Rush, R. R., Oukrop, C. E., Sarikakis, K., Andsager, J., Wooten, B., \& Daufin, E. K. (2005). Junior scholars in search of equity for women and minorities. Journalism \& Communication Monographs, 6(4), 151-211.

Tuchman, G. (1978). Making news: A Study in the construction of reality. New York, NY: Free Press.

UN Women. (1995). Beijing declaration and platform for action. Retrieved from http://www.un.org/ womenwatch/daw/beijing/platform

Vos, D. (2012). Is gender bias een mythe? Op zoek naar verklaringen voor de beperkte aanwezigheid van vrouwelijke politici in het Vlaamse televisienieuws [Is gender bias a myth? In search of explanations for the limited coverage of female politicians in the Flemish television news]. Res Publica, 54(2), 193-217.

World Association for Christian Communication. (2015). Who makes the news? London: World Association for Christian Communication.

World Economic Forum. (2017). The global gender gap report. Geneva: World Economic Forum.

Zoch, L., \& VanSlyke Turk, J. (1998). Women making news: Gender as a variable in source selection and use. Journalism \& Mass Communication Quarterly, 75(4), 762-775.

\section{About the Author}

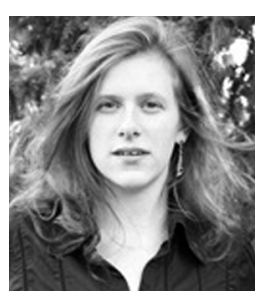

Hanne Vandenberghe (PhD, University of Leuven) is a Senior Researcher/Lecturer at the Faculty of Social Sciences at the University of Leuven. Her PhD is titled News diversity: A Longitudinal and Comparative Perspective in which news diversity was mapped from the perspective of the content in terms of actors, sources and issues, the journalistic perspective and the perspective of the public. She is interested in the representation of ethnic minorities and women, the journalist-source relationship and news audience demographics. 